\title{
The Death of the Angel: \\ Reflections on the Relationship between Enlighten- ment and Enchantment in the Twenty-first Century ${ }^{1}$
}

\author{
RUTH BEHAR \\ University of Michigan
}

\begin{abstract}
Tango artist Astor Piazzolla's composition, 'La muerte del ángel', serves as inspiration for a few reflections on the relationship between enlightenment and enchantment in the 21st century. Piazzolla wrote the fugue as accompaniment to a play, 'Tango del angel', about an angel who tries to heal broken human spirits in Buenos Aires and ends up dying in a knife fight. Drawing on tango's melancholy, longing, and hesitant hoping, I share stories from my travels where I engage with the struggle to sustain an ethnographic art that brings heart to the process of knowing the world.
\end{abstract}

Keywords: ethnography, reflexivity, tango, writing

The tango, a form of music, song, and dance, as well as a sensibility, a way of being in the world, was born in Argentina. But I first heard the tango and felt it and fell in love with it in Cuba, my native land.

Daniel Esquenazi Maya, an old and impoverished man who lived in a rooftop apartment in Old Havana, gave me my first introduction to the tango. Daniel was one among a handful of Jews who didn't want to be uprooted and stayed in Cuba after the Revolution that brought Fidel Castro to power in 1959. Most Jews left soon afterward. The Communist expropriation of properties, stores, businesses, and miniature enterprises, like door-to-door street peddling, on which many Jews depended for their livelihood, led to a mass exodus from Cuba. As a child of four and a half, I was part of this exodus of fifteen thousand Jews, though I don't remember it. Among the thousand Jews who still remain in Cuba today, most are of mixed heritage and have become converts to Judaism, or 'Jews by choice'. A few are oldtime Jewish atheists and dedicated Communists, still filled with faith in the goals of the Revolution.

1 Presented at Aboagora symposium, Turku, Finland on August 18, 2011. 
Daniel's parents were Sephardic Jews from Turkey. While not religious, when he became elderly and a widower, fearing that the temple of his youth would be shut down if no one took charge of it, Daniel agreed to serve as the president of the oldest synagogue in Cuba, the Chevet Ahim, built by Sephardic Jews in 1914. Eventually it was closed due to the ruined state of the building and the possibility of the roof collapsing. Daniel then attended religious services at Adath Israel, an Orthodox temple a few blocks from his home, where his thunderous singing rose above the others when intoning prayers and chants. Daniel loved to sing, but he never concealed the fact that part of the reason he attended was because the temple gave the elderly a bag of food and an allowance each week. After the fall of the former Soviet Union, the subsidies on which most Cubans depended had been whittled to a little bit of rice and split peas. Hustling and charity were needed to survive. Daniel, like many others, depended on both.

I first met Daniel when I began to travel back and forth to Cuba in the early 1990s. Sitting on the women's side of the temple, I was mesmerized by Daniel's singing. That voice, I learned, had been trained through years of being a tango singer. Daniel spent all his weekends singing tango songs at local cultural clubs in Havana. On several occasions I went with him and saw this world of tango enthusiasts up close. They didn't dance the tango, but they sang until they moaned and cried, the lyrics and tunes enough to leave them grief-stricken. Tango was Daniel's great passion. He belted out the songs, in Spanish peppered with Argentine or lunfardo slang, every chance he got, not just at the clubs. His neighbors, he said, thought he was a madman on the roof, singing his tango songs even when no one was listening.

Daniel was one of the most frequently photographed, filmed, and interviewed Jews on the island, where Jews have become an exotic tribe, a rare fauna observed constantly by tourists, anthropologists, and well-wishers. I am guilty of being part of the pack of onlookers who turned Daniel into a celebrity. When I heard he was a tango aficionado, I asked Daniel to sing for my movie, Adio Kerida/Goodbye Dear Love (2002). He crooned Mi Buenos Aires Querido (My Beloved Buenos Aires) with the brokenhearted nostalgia of an immigrant, even though he'd never been to Buenos Aires. In fact, he'd never left Cuba.

He had more than two hundred singles, old 78s, of songs once sung by Carlos Gardel, the great icon of Argentine tango. Enamored of Gardel since his youth, Daniel had an entire wall in his apartment that was an informal shrine to the great Argentine singer, who died young in a plane crash at the height of his international popularity. 


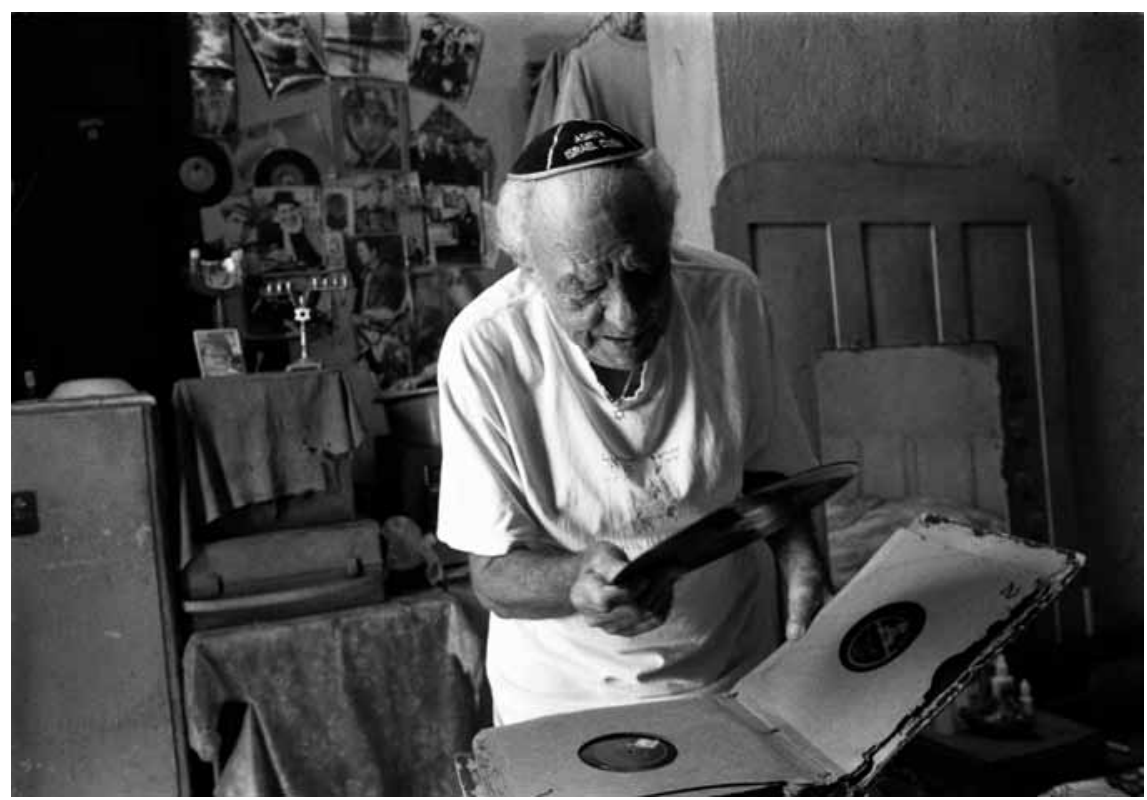

Daniel Esquenazi Maya in Havana looking through his old tango records. Photo by Humberto Mayol, 2006.

When I interviewed Daniel in 2001, his record player, which he had purchased in 1960 for 160 pesos, still worked. He played tangos for me from his collection and they sounded glorious, all their breathy drama intact. But five years later, when I visited him again at his rooftop apartment, he told me he couldn't play his tango records anymore.

'My record player broke. There isn't a soul in Cuba who knows how to fix it', he said. 'It's nobody's fault. They don't make record players like this anymore.'

Daniel took a stoical attitude to the loss of his record player. Perhaps, growing older, material possessions were of less use to him. He was gaunt, his hair had thinned, and he struggled to get up the last flight of shaky wooden stairs to his rooftop apartment.

'I still enjoy looking at the records in my collection', he said. 'I remember all the tangos. I can hear them in my head.'

Later on, in July of 2008, after I finished my book, An Island Called Home (2007), which featured a chapter about Daniel, I went to visit him and learned he was recovering from heart surgery. He struggled to get used to a pacemaker while suffering from severe asthma. Barely able to leave his bed, his rooftop home had become a prison - he couldn't go down the stairs 
to reach the street. Neighbors who'd once ignored him now competed to care for him, hoping to cart away, once he died, whatever meager goods and money Daniel had saved.

I asked Daniel if he'd sing a tango. He smiled sadly and half-sung, halfwhispered the exilic words that were immortalized by his beloved Gardel:

Mi Buenos Aires querido

Cuando yo te vuelva a ver

No habrá más pena ni olvido.

My beloved Buenos Aires

when I see you again

there will be no pain or forgetting.

Again we were in Havana, in Cuba, and Daniel was singing for a lost Buenos Aires. The moment was worthy of a poem, but I remembered I had to be an anthropologist and snapped a few pictures of him, shirtless, his ribs protruding from his emaciated frame. As I said goodbye, he asked for a dollar. I gave him a couple of dollars and he clutched them tightly in his hand.

This would be the last time I'd see the man from whose lips I first heard the tango.

Thanks to Daniel, I have come to love the tango. I love its melancholy. I love its lyrics, which express an obsession with lost things, lost places, lost passions, and inconsolable goodbyes. I love the dance because you move through space with another person of the opposite gender in a silent yet meaningful conversation, embodying loss and time's inevitable passing in the three or four minutes that a tango lasts. All the while, you stay loyal to the rhythm of the music, haunted with farewells and the longing to return to memories better left forgotten.

I took up dancing the tango at a time in my life that was very painful for me as a mother. My son, Gabriel, then twelve years old, a gifted natural athlete, had seriously injured his knee, tearing his anterior cruciate ligament in a sports accident. It became wrenching to pass a soccer field, to see kids playing basketball at an outdoor court. Those activities were forbidden to Gabriel. He never complained, but I'd notice a cloud of sorrow pass over his eyes as we drove past and saw other kids sweating from the strenuous physical activities he loved and once excelled at. My athletic child had 
developed an invisible disability. He appeared normal, but he was not to jump, run, twist, or turn - and certainly not dare to dance, as the doctor had warned. Gabriel had lost the ability to move freely, to move without thinking.

While my husband was more relaxed about Gabriel's injury and had faith that he'd heal, I was very distressed because I'd also been injured as a child, at the age of nine, and had been in a body cast for a year due to a complex fracture of my right leg. It had taken me another year to learn to walk again. My destiny changed afterwards. I became sedentary, afraid to fall and hurt myself. I became a girl whose greatest pleasure was reading books. I wasn't ready yet to see my son's destiny change. I wanted him to be the athlete I had not been.

Who could have predicted that in my 40 s I'd take up the sensual pastime of dancing tango? I'd reached the age when I should've been reading the Kabbalah. Instead, a couple of times a week, I joined a bunch of strangers who patiently tried to balance each other's bodies in space while listening to sad songs from Buenos Aires. A friend in Michigan had told me about the local tango club, headed by a woman from Argentina who'd also recovered from a serious leg injury. 'I bet you'll love it', she said. She was right. But they say you can love the tango, though it doesn't necessarily love you back. That's how it was for me - for years, tango was my greatest unrequited love. I hobbled around the dance floor as heavy as furniture that had to be lifted and carried. Slowly, ever so slowly, I improved. Once I could do basic things, like walking backwards in high-heeled stilettos, and keep my posture and embrace from sagging while being led into moves that made me feel I was about to levitate, tango became an essential form of self-expression.

Being led around the dance floor, sometimes with my eyes closed, as I was advised to do in order to enter a 'tango trance', I was frequently in tears as I thought about the limitations on my son's movements. Tango became a way to tell, without words, the story of my anguish about Gabriel's loss of his athletic gift. It was an anguish I carried with me from day to day, unable to speak about it because I didn't want to sadden him.

It was amazing to me to discover the range of men I could dance with as I got better - tall, short, thin, husky, young, old, it didn't matter. I could dance with men, Polish or German, who in another era might have cooperated in my destruction, who would have only seen the Jew in me. I could dance with men, Palestinian and Arab, who in another place might have only seen the enemy in me. Tango, like yoga, could quell unease, quiet the mind of its prejudices and worries and hatreds, and, with regular practice, bring about peace. 
Leopoldo Marechal calls the tango 'una posibilidad infinita' - an infinite possibility (Marechal 1966, 73). According to the musicologist Ramón Pelinski, there are two ideal types of the tango (Pelinski 2000). First, there is the 'tango porteño', rooted near the port of Río de la Plata, specifically the city of Buenos Aires, where the tango was born at the turn of the twentieth century in the brothels. Then there is the nomadic tango, the tango that has been dispersed around the world, in diaspora upon diaspora, reterritorialized amidst different skies and seas, as Argentines have moved from place to place taking the tango with them, and as foreigners from everywhere have felt themselves drawn to the tango and have carried it to unexpected locations. These days, with globalization, the two forms of the tango collide and crisscross, and are virtually inseparable. But this wasn't always true.

In classical anthropology we focused on cultural diversity and cultural stability; but in contemporary anthropology, in an era of great immigration and displacement, we are aware of culture as mobile, portable, on the move. The mobility of culture is very evident in the history of the tango. The Finnish tango is one example of such cultural mobility. The tango was brought to Finland by seafaring Finnish men (who may have spent time visiting the brothels of Buenos Aires), and was reinvented by them and their descendants in Finland. The Argentine sense of melancholy and longing that is embedded in the tango was reborn in Finland and given a Finnish sense of melancholy and longing.

Probably there is no single musician or composer who has had as strong an influence on the global appreciation for the tango as Astor Piazzolla. Between the 1940s and 1980s Piazzolla struggled to invent a new tango, a tango that came from his feelings, a tango meshing the soul of Argentina with the influences of American jazz and European symphonic music. The grandson of four Italian immigrants, an Argentine by birth and an immigrant child who grew up in New York, Piazzolla was equally fluent in English and Spanish - having lost his Spanish while growing up and coming of age in New York, he regained it upon returning to Argentina. He was born with a defective right leg and as a small child required several operations, leaving that leg two centimeters shorter than the other (Azzi \& Collier 2000, 5). While still a boy in New York, his father bought him a bandoneon at a second-hand shop. The bandoneon, the concertina brought to Argentina by German sailors and Italian workers, is an instrument that breathes in and out with an eerie likeness to the human lungs, joining with the violin, guitar and piano to create classic tango music. This gift to Piazzolla from 
his father delivered a strong cultural message: don't forget the tango; don't forget you are Argentine (Azzi \& Collier 2000, 134).

Piazzolla didn't forget. But he longed for a tango that was neither singable nor danceable, a tango that 'appealed to the ear rather than the feet', a tango that belonged not to the world of the cabaret but in concert halls. Like his father, he moved between Argentina and New York throughout his adult life. In addition, he spent many years living in Paris. Piazzolla's first major breakthrough as a composer took place after the death of his father in 1959 while he was performing in Puerto Rico. The loss of his father inspired him to compose, upon his return to New York, a haunting lament, 'Adiós Nonino' - 'nonino' for grandfather in Italian, the name by which his son and daughter called his father. Composed while weeping as he'd never wept in his life, he considered it the 'finest tune I have written', and reflected, 'Perhaps I was surrounded by angels'. (Azzi \& Collier 2000, 76.)

But success didn't come easily. Piazzolla's life was one of continual struggle to create his new tangos. He innovated on the style of performing the tango as well. On stage he refused to sit down to play, instead standing tall with his bandoneon, which he opened and stretched to its limits. For this, in Buenos Aires, he was greeted by fury and fervor. In the 1960s, street fights broke out between piazzollistas and anti-piazzollistas. Piazzolla himself was not above throwing a few punches with his strong left hand. There were taxi drivers who wouldn't take him because he had 'destroyed the tango', and other taxi drivers who refused payment - 'Maestro, please you're offending me'. (Azzi \& Collier 2000, 79-80.) It was said of him that he was for Argentina 'what the Beatles were to the world'. He transformed 'a tradition of popular music into something authentically his own'. In the process, 'he succeeded in universalizing Argentine tango music'. (Azzi \& Collier 2000, 282-3.)

Still, he kept his Argentine roots, and could communicate something unutterable that shone at the core of tango culture: a mode of spirituality that was neither religious nor secular, and yet drew from both, and transcended both. It was the ability to evoke the presence of angels that makes his music like no other. For this knowledge he drew from many sources, including the theater, in particular the plays of Alberto Rodríguez Muñoz. He had the good fortune to compose 'The Death of the Angel', a fugue, for 'The Tango of the Angel', the last play in a trilogy by Rodríguez Muñoz. This tango accompanies the story of an angel who attempts to heal broken human spirits in a Buenos Aires tenement, only to die in a knife fight. As the play comes to a close, one of the characters describes the angel as 'an angel 
we created out of the fury of our own impoverished dreams. A true angel, not an angel from God, who is in the heavens, so far from this squalor, but an angel that was ours, made by our desires, birthed by us.' (Rodríguez Muñoz 1965, 208.) This is the angel that inhabits Piazzolla's work: an angel that was once human, still is human, an angel seeking freedom, the angel to whom Piazzolla later gave a different voice in 'Libertango'. Tango on behalf of liberty, on behalf of freedom - tango to resurrect a dead angel.

Piazzolla is an inspiration to me in many ways. Since my days as a graduate student, I have come to anthropology wanting to be a writer, an artist, and yet drawn to the philosophical ideas at the heart of this discipline, which mirror so perfectly the twists and turns of post-enlightenment thinking. I've struggled with my profession, tried to make it something other than what it is, while still calling myself an anthropologist.

The discipline of anthropology took form at the turn of the twentieth century. It was anthropologists, most of them privileged and well-educated white Euro-American men, who brought back dispatches from such places as New Guinea, Africa, Alaska, and South America, places that from a Euro-American perspective appeared to be at the ends of the earth. This was the era in which Robert Flaherty made 'Nanook of the North' (1922), a documentary about the Inuit - or Eskimo - premiering his work in Paris to great acclaim at the very moment when the smiling, good-natured man he called Nanook, whom he lauded as a survivor of the wild North, was starving to death after a failed hunt.

Anthropology took it upon itself to give meaning to 'the savage slot', constructing an 'Other' that existed in opposition to the 'West' (Trouillot 2003). The 'Other' had held on to ancient traditions and superstitions, and though mired in poverty, seemed to live contentedly, in a world of 'enchantment'. In contrast, the anthropologist, and the society he represented, had become modern and scientific. The 'enlightened' condition of modernity ought to have guaranteed happiness and peace, but instead civilization had brought about anxiety and discontent. It was the search for an understanding of this paradox that inspired the journeys of the earliest anthropologists. Torn between the world they came from and the world they journeyed to, they justified the superiority of modern life, yet waxed nostalgic for the simpler magical life of 'the Noble Savage'.

Eventually, the need for anthropological dispatches from the ends of the earth became obsolete. Following two brutal European world wars, 
the entire world became accessible to a much larger number of people than at any other time in human history. After decolonization, the old distinction between the 'civilized West' and the 'barbaric non-Western Other' ceased to make sense. Though the connection is rarely made in histories of anthropology, the testimonies of the Holocaust revealed the savagery nestled in the very heart of the Western world. Who, then, was calling whom a savage? Was the price of enlightenment a greater ability to do evil in the world?

In the 1960s and 1970s, American anthropology was further challenged in the wake of the civil rights movement, the anti-war movement, the feminist movement, the Native American movement, and the Chicano movement. Gender, race, and class, the trinity of categories that have become so central to the way we analyze the world, exploded the social theories anthropologists had previously worked with. These enormous transformations might have spelled the end of anthropology, but instead a range of new anthropologies emerged that sought redemption for the discipline and restored history, agency, and geographic mobility to ethnographic subjects. Feminist anthropology, activist anthropology, reflexive anthropology, and native anthropology were born from the ashes of a disgraced anthropology. Miraculously, the most seemingly antiquated of the social science disciplines became one of the most provocative and progressive. Now cultural anthropology, as a profession, is more inclusive of women, people of Latin American, Asian, and African descent, Native Americans, and people of working-class background - scholars who in the past would have been anthropological 'Others' but are now anthropologists in their own right. The presence of these post-anthropological 'Others' has brought about a necessary rethinking of ethnographic authority and subjectivity, and put issues of 'love and rescue', in the words of Virginia Dominguez (2000), at the forefront of our practice.

Many of us feel that at the core of what cultural anthropologists do is ethnography - which is both a method for entering into the lives of others, and an artistic form of expression, a way of telling a story (Behar 2003). Ethnography emerges from a unique and fleeting encounter between an ethnographer and the individuals who choose to become the subjects of the ethnography. Like dancing a tango, where two people become one in their movements, ethnographies can lead us to a border where the story of the observer and the story of the observed threaten to blur and dissolve. Our lives become wound up in the lives of others and we form messy, awkward, uncertain bonds. Somehow from these bonds we piece together a science... 
a social science.... a human science... In my case, ethnography is a blurred genre, which permits me to mix ethnographic stories that emerge from fieldwork with analysis, commentary, cultural criticism, family history, and personal reflections.

The life of an ethnographer is a haunted life. We spend so much time listening to the stories of others that we can hear all those voices in our heads. We are constant witnesses to human agony and hope. And we are worriers, asking ourselves over and over if there was more we could have done to be present, to be compassionate, to give back to those who gave to us. We work with people who are usually total strangers at first, but as we get to know them, through the close bonds created by ethnography, we come to feel inextricably tied to one another.

I find that even strangers I have no interest in knowing will confess their hopes and sorrows to me when I sit next to them on the plane or the train or wait together on a long checkout line at the grocery store. Somehow, without saying a word, I communicate my capacity to listen, my willingness to listen, wherever I go. And the thing is most of the time I really am 'all ears' and my accidental listening will do that other person so much good he or she will actually thank me and be sorry to part ways with me. But sometimes I just want to be off-duty as an anthropologist and I'll try hard to look the other way or crack open a book, but even then someone insists on baring his or her broken heart to me. There's an aura about those of us who are professional listeners that there's no escaping from.

In addition to this predisposition toward being listeners, we have another quality we can't let go of. While we cherish each individual life and believe that every person has a story to tell, a story that is a world onto itself and deserves to be heard and honored, we also have great confidence in communities, and believe the work we do must serve a bigger world. We are tense observers of the boundaries between the individual and society. That is why we're drawn to people at risk, people on the border, people on the margins, people who are outcasts, people on the edge between life and death, people who can push us to think about how to be independent and connected to others at the same time. We feel not just concern, but shame, about the inequalities in our society and around the globe. We dedicate most of our energy to bringing attention to those who lack the power and the means to make themselves be seen and heard.

We care about those whom no one else cares about. We love those who are unloved, and rescue those who don't even realize they are lost and need a map to find their way home. In the process we learn to love and rescue 
ourselves and come closer to creating the homes that we need in order to be able to nourish our own spirits and intellects so that we can go on being such intensely caring listeners. Our research projects can and should open the doors of the soul.

Ours is a world that is humane in unprecedented ways. There is more awareness of individual needs and the potential for personal fulfillment is at an all time high. As our world grows smaller and more homogeneous, there is a greater appreciation for the heritage that each community brings to our vast human mosaic, greater tolerance overall of cultural differences. There is a heightened consciousness that language that is sexist, racist, and homophobic is wounding and will not be tolerated. We have made our streets and buildings accessible to all sorts of people - able-bodied and disabled alike. Whatever its shortcomings, the internet revolution, which brought us Google and You Tube, has made more of the world's knowledge available to more people. We shouldn't shy away from taking pride in the spirit of greater empathy and understanding that has come about in our post-Enlightenment era. As Rebecca Solnit puts it in Hope in the Dark: Untold Histories, Wild Possibilities, 'we inhabit, in ordinary daylight, a future that was unimaginably dark a few decades ago' (Solnit 2004, 28).

At the same time, there are terrible, violent divisions around the world, and it is perhaps those who occupy spaces 'in between' that can help to bring about understanding and cooperation. As Amin Maalouf points out In the Name of Identity: Violence and the Need to Belong, there is the danger of reducing identity to a single affiliation, which 'encourages people to adopt an attitude that is partial, sectarian, intolerant, domineering, sometimes suicidal, and frequently even changes them into killers or supporters of killers'. The recognition of mixed identity, on the other hand, helps to promote peace. As he notes, 'a man with a Serbian mother and a Croatian father, and who manages to accept his dual affiliation, will never take part in any form of ethnic "cleansing". A man with a Hutu mother and a Tutsi father, if he can accept the two "tributaries" that brought him into the world, will never be a party to butchery or genocide.' (Maalouf 2001, 4.)

Air travel, the media, the web, and globalization have brought human beings closer, making possible numerous intercultural encounters that would have been inconceivable in the past. If tragedy strikes anywhere, we learn about it instantly. All of us are unwitting experts on genocides, wars, rapes, disasters, plagues, cancers, tsunamis, famines, and earthquakes. Our capacity to feel compassion for another's suffering is put to the test each and every day, in a way that earlier generations never knew. 
Much of the horror in the world that we experience comes to us in a virtual format. We are exquisite spectators, watching human sorrows unfold on a computer or TV screen. When we tire of it all, we can power off. The fact that we can power off is both terrible and fortunate. We'd go crazy if we didn't power off and enjoy life. But it is also possible to be driven crazy by thinking about all the horror in the world that we're doing nothing about. It is overwhelming to know so much about what is happening in the world and to recognize that we can do so little.

What a challenge it is for us, then, to continue to be caring listeners, for us to continue doing our work, slowly building an understanding of just a few human beings at a time, slowly learning in detail the dilemmas those human beings face in sustaining their own humanity. Our work can at times seem so small, so miniature; no more than a grain of sand that won't make a difference, won't make things better. But we know that every act of kindness counts, and the more we multiply kindness, the greater our chance of challenging the heartless rationality of evil with the heart-filled irrationality of the good.

Most of the world doesn't understand the work we do. We aren't doctors who can fix broken bones or remove cancers from anyone's brain, nor are we novelists who can sweep you off your feet with a story about an adulteress who can't decide whether it's her husband or her lover who makes her more miserable. And yet, though it may seem surprising, we have only a little bit of the doctor and a lot of the novelist in us (Behar 2009). Our greatest asset is our compassion, our ability to enter the stories of others with such thoroughness that they come to haunt not just our waking lives but our dreams as well. Unlike novelists, our imaginations are in service to real individuals and real communities that we come to know firsthand.

But we incur a debt to the people who consent to work with us that can never be paid back. In fact, this contractual metaphor is wholly inadequate to describe the relationships we form with our subjects. While we are helping them by providing a sensitive ear to their stories, they give us something greater - the gift of their trust. We promise to listen faithfully to what they have to tell us and to share their stories truthfully with the rest of the world, while trying to make sure we don't cause any harm or hurt or humiliation. That is a huge responsibility we take on. I don't know if it's humanly possible to really make good on our promise. We try our best. I think it's amazing we can sleep at night. 
Another thing ethnography has in common with the tango is sorrow. The soul of the tango is sorrow. There is sorrow, too, at the soul of ethnography. Let us not forget Lévi-Strauss and his Tristes Tropiques (orig. 1955), his sad tropics. Loss is a classical trope of the ethnographic imagination. The practice of ethnography originated in the desire to salvage fragments of societies that appeared to be on the verge of extinction. Ethnography engaged in a language of loss - of preventing loss, mourning loss, arriving just in time to save cultures from oblivion.

Sorrow and loss were emotions I felt strongly when I started out in my career. Working in a village in León, in northern Spain, I found myself in the company of aging farmers who had an intimate relationship to the earth. I was very young when I first knew them, in my early twenties, and they took me in as a kind of granddaughter and they showed me how it hurt your kidneys to pick potatoes and how it hurt to be left behind by everyone. People kept rabbits, chickens, pigs, sheep, and cows in stables adjoining their houses. The summer months were occupied with gathering hay, harvesting wheat and rye, caring for vegetable gardens, and picking pears, cherries, and apples. Winters, besides being long, were bitterly cold, and you stayed in the kitchen most of the day, because it was the only heated room. It was the late 1970s and early 1980s. The post-Franco transition had just begun. These farmers felt abandoned by their children and grandchildren, who had left the countryside for the city as part of a mass exodus. Out of nowhere, I appeared, sent there by a professor, mysteriously, like an angel, to ask them for their stories, to bear witness to their poignant efforts to remain on the land at moment when urbanization, the growth of commodity culture, and corporate globalization made it seem foolish and backward to continue to grow your own food in absurdly little villages where everyone knew each other. It would take years for the organic food movement to arise, and for there to develop awareness about protecting the beauty of local spaces and customs - back then, the villagers I met felt no pride; they were ashamed and humiliated to be working 'like brutes' on the land.

Although I'd never lived in the countryside before, I wasn't a total stranger to the reality I was witnessing. I spoke Spanish, even if it was Cuban Spanish rather than Castilian Spanish. And the more time I spent in Spain, the more I thought about how, as a Sephardic Jew, I had a connection to this land and this people that went way back. My ancestors, five hundred years ago, before the expulsion, had thought of Spain as home. But all this felt unspeakable to me. Living with farmers who were devout Catholics, I kept my Jewish claim to a connection to Spain quiet. I went to mass every 
Sunday with everyone in the village. In the bedroom where I slept, I took down the crucifix each night and put it back in its place on the wall the following morning.

Why did I act in this way? People had taken me in and come to accept me. I worried about losing their protection and love. I worried about being expelled, like my ancestors. And so I hid. Hid from them, hid from myself.

The dissertation I wrote about the village was serious and scholarly, and it led to my getting a job as a professor at the University of Michigan, but I was disappointed with it. I wished it had had more heart, more feeling. It was only when my lie exploded in my own face, after my grandfather died in Miami while I was back in Spain doing additional research on death customs, that I began to do the writing I considered meaningful. I'd learned through fieldwork to recite the rosary in Spanish and had come to know the mass by heart, but I didn't know how to mourn for my grandfather as a Jew. I was an anthropologist who was woefully ignorant about my own traditions. Writing about that realization, in an essay I entitled 'Death and Memory', was my first stab at being a vulnerable observer. This writing was still an act of cowardice. I never told anyone from the village I was Jewish until decades after I'd completed my fieldwork.

Now, so many years later, the grandchildren and great-grandchildren of the people I knew in Santa María have found me on the Internet, and they've written to thank me. The book that came from the dissertation, The Presence of the Past in a Spanish Village (1986), that I so desperately wished could have been better, for this younger generation has become a crucial document about the traditions and way of life of their ancestors, whom I was blessed to know. Recently, a young man from one of the neighboring villages, who studied anthropology, has taken it upon himself to translate my book into Spanish. His dedication has moved me deeply; his attention to detail has been meticulous. He's done it, he says, for his father; so his father can read my book. This act of love is huge; it has reminded me that always at the core of ethnography is the gift - the gift of stories given, received, and written down, not knowing who'll need them. As Rebecca Solnit says, writing is 'an intimate talk with the dead, with the unborn, with the absent, with strangers, with the readers who may never come to be and who, even if they do read you, will do so weeks, years, decades later. An essay, a book, is one statement in a long conversation you could call culture or history; you are answering something or questioning something that may have fallen silent long ago, and the response to your words may come long after you're gone and never reach your ears - if anyone hears 
you in the first place... No one is more hopeful than a writer, no one is a bigger gambler.' (Solnit 2004, 64.)

$* * *$

After the years in Spain, I went on to Mexico, and now it was a desire for feminist solidarity that drew me into a complex relationship with a Mexican street peddler named Esperanza. Ethnography, like the tango, is an effort to find a connection between human beings. But I soon discovered that not I, but Esperanza, was the one who would establish the terms of our connection. She never let me forget that I, though a Cuban immigrant, could cross the border easily between the United States and Mexico, but she couldn't because she was poor; I was the one who could write her story, not she, she was illiterate. She forced me to reflect on my privilege as a writer and ethnographer, and in that way, she helped me to write a daring book that questioned the very act of writing another woman's life story as I still attempted to tell her life story (Behar 1993).

Our relationship was based on an unspoken but very real contract, an exchange of desires and longings, in which she told me her story in the presence of her younger children so I might validate the decisions she'd made in her life, and I listened to her story so I could write a book that would help me to become the feminist ethnographer I didn't yet know how to be. Her story was given to me in the context of the spiritual kinship we'd formed as comadres ('co-mothers'), and there were real things Esperanza expected and wanted from me, which included a television, a VCR, and financial support when her luck was down. She didn't ask for it, but I also gave her shares of the royalties. Was that enough to give back to her after she'd given me the gift of her story - a story that helped me rise up in my academic career? I didn't know. I'd never know.

Esperanza didn't realize that through her life, and the historias (the 'histories' or life story) she told about her yearning for freedom as a woman, she was helping to tell a larger story than her own - the story and the history of modern feminism. She knew she suffered seeing her mother suffer from violence. She knew that she, like her mother, also endured the pain of beatings, and that the beatings left scars on her body. Long before feminism reached her small town in northern Mexico, she refused to live a life she found intolerable. She left her abusive husband and went to work as a street peddler to support her children. She understood in her heart - though there was no official confirmation of it anywhere in her social world - that her historias mattered. Alone and wretched, but she had her historias. No 
one could take them from her. Her historias, she rightly believed, were her capital, her riches.

When Esperanza was a young woman, struggling to find her way out of the soul-crushing cycle of domestic violence, there were no resources to support her, no experts to counsel her. The feminist movement and the discourse of women's equal rights had not yet universalized the idea that women are full human beings who deserve to have the same opportunities as men to develop their intellectual and creative gifts without fear of discrimination, abuse, and oppression. But before feminism existed, there were brave women. Esperanza was one of these brave women. Although disparaged as a bruja, a 'witch', she had been unafraid to speak out and protest the injustice of her condition. We recognize now that it was through the struggles of many women like Esperanza that feminism came into being.

There is now a new office in Esperanza's hometown dedicated to solving problems of 'violencia intrafamiliar' (intrafamilial violence). A lawyer and a psychologist are available on a daily basis to provide services, at no cost, to women and children in need, and to help sustain 'una vida sin violencia' (a life without violence). Esperanza's voice, as well as the voices of so many women who have suffered in similar ways, are being heard, at last, in Mexico. And Translated Woman, which I thought would mainly be of interest to people who cared about Mexico, is now read by women prisoners in American jails, who find in Esperanza's story relevant clues to understand how violence in their own lives has led them to face imprisonment and diminished futures. As Rebecca Solnit says: 'History is full of small acts that changed the world in surprising ways.'

$* * *$

There is always one more story to tell after the last story has been told. Here it is. Long before Daniel Esquenazi Maya died, I went to Buenos Aires. I saw the city he sang about so passionately, the city he never saw with his own eyes. I showed Adio Kerida to many people there, and everyone loved the scene of Daniel singing 'Mi Buenos Aires Querido'. I kept meaning to tell him I'd gone to Buenos Aires, but I never got around to it. A part of me was afraid it wasn't fair that I'd been able to go rather than he. Perhaps that's why I never told him.

In Buenos Aires, I had a strange feeling I belonged in that city that felt so distant, so southern, so far from everything and everybody. I reasoned it had to do with the fact that my maternal grandfather, a Russian Jew, was supposed to have met his older sister there, back in the 1920s, but 
he'd somehow gotten on the wrong boat in Europe and disembarked in Havana, thinking he'd arrived in Buenos Aires. Afterwards, neither he nor his sister had enough money to be reunited. Many years later, after my grandfather was old, and his sister even older, he got on a plane in Miami with my grandmother and went to see her. Then, until the day he died, he sent packages every month with clothes, shoes, anything he envisioned his sister and her family could use.

My great-aunt's daughter and two of her grandchildren, who are close to me in age, are still in Buenos Aires, so I can say I have family there in that city that might have belonged to me. I take comfort in that. I am left to wonder about the turns of destiny that made me born in Cuba rather than in Argentina.

Late at night, my cousins don't know this, but all by myself I go to the milonga in hopes of dancing. As a woman, you never know if you will be asked to dance. But you hope. You can love the tango; it doesn't necessarily love you back. I am older, I am a woman of a certain age, I understand that very well, though Marta Savigliano (2003), an expert on the tango, says that the milonga environment 'defies accepted parameters of old and young [...] and mature women are still in the running [...] because what matters is the confidence with which the milonguera moves her body on the dance floor'. I find that this is true enough of the time to encourage me, as well as other women my age, and even older, to keep going back.

They don't play Piazzolla's tangos at the milongas in Buenos Aires. They play the tangos from before his time, before his revolution, as if Piazzolla hadn't existed. His music still isn't viewed as danceable - it's for listening, for the shows, or for acrobatic tango dancers, not for the ordinary insomniacs who want to dance away their evenings, and in the best of situations, reach a point of such strong connection that both the follower and the leader are dancing with their eyes closed. But I like to think that Piazzolla's angel is always there at the milongas, keeping watch over all of us, a little sad, but very patient.

Do I need a conclusion? A friend read this essay in advance of my presentation and said I did. What do you think? Yes? Well, I will try to my best to conclude.

Having gone with me on this journey, with so many stops and starts, how do I tie it all together for you? What did I want you to learn along the way? Yes, tango is like anthropology, and anthropology is like tango. An- 
thropologists are always desperately trying to save the present before it is past and over. We can learn from the tango to dwell in the moment, even as the music pushes us to contemplate the eventual loss of everything we love.

And the symbol of the angel - what is the angel?

Enlightenment? Yes, because the angel has been present every time we, as human beings, have expanded our notions of freedom and justice.

Enchantment? Yes, because the angel is in us when we create, tell stories, play music, make art, dance, meditate, and love the world more than ourselves.

So the angel is a bit of both - enlightenment and enchantment. Not at all a rosy cherub, but the human angel of Piazzolla's tangos.

It is impossible to speak of the angel without mentioning Walter Benjamin. He famously wrote, 'the face of the angel of history is turned toward the past $[\ldots . .$. . The angel would like to stay, awaken the dead, and make whole what has been smashed. But a storm is blowing from Paradise; it has got caught in his wings with such violence that the angel can no longer close them.' (Benjamin 1968.) These bleak words were set down on paper in 1940. Expecting to be turned over to the Nazis by the Spaniards, Benjamin committed suicide only a few months later, an act of courage and resistance.

But these are different times, aren't they? Have we learned from history? Dare we now imagine an angel of hope, with its face turned toward the present? And even toward the future? More than ever, we need faith in the future, the kind of faith called upon to bring about change for the sake of the long term, change we might not benefit from in our own lifetime, change we want those who come after us to enjoy and cherish and pass on to those who will come still later. Let us have faith in those tangos no one can yet sing, or dance, or hear, or even begin to imagine.

Bibliography

Azzi, María Susana \& Simon Collier

2000 Le Grand Tango. The Life and Music of Astor Piazzolla. Oxford: Oxford University Press.

Behar, Ruth

1986 The Presence of the Past in a Spanish Village. Princeton: Princeton University Press. 
1993 Translated Woman. Crossing the Border with Esperanza's Story. Boston: Beacon Press.

2002 Adio Kerida/Goodbye Dear Love: A Cuban Sephardic Journey. New York: Women Make Movies.

2003 Ethnography and the Book That Was Lost. - Ethnography 4 (1), 15-39.

2007 An Island Called Home. Returning to Jewish Cuba. New Brunswick, New Jersey: Rutgers University Press.

2009 Believing in Anthropology as Literature. - Alisse Waterston \& Maria D. Vesperi (eds), Anthropology Off the Shelf. Anthropologists on Writing, 106-16. Malden, MA: Wiley-Blackwell.

\section{Benjamin, Walter}

1968 Theses on the Philosophy of History. - Illuminations, 253-64. New York: Harcourt, Brace, and World.

\section{Dominguez, Virginia}

2000 For a Politics of Love and Rescue. - Cultural Anthropology 15 (3), 361-93.

\section{Lévi-Strauss, Claude}

1992 Tristes Tropiques. New York: Penguin Books.

\section{Maalouf, Amin}

2001 In the Name of Identity. Violence and the Need to Belong. New York: Arcade Publishing.

\section{Marechal, Leopoldo}

1966 Narración con espía obligado. - Juan-Jacobo Bajarlía et al., Crónicas con espías. Buenos Aires: Editorial Jorge Álvarez.

\section{Pelinski, Ramón}

2000 El tango nómade. Ensayos sobre la diáspora del tango. Buenos Aires: Corregidor.

\section{Rodríguez Muñoz, Alberto}

1965 Melenita de Oro, Los Tangos de Orfeo, y El Tango del Ángel. Buenos Aires: Editorial Sudamericana.

\section{Savigliano, Marta}

2003 Nocturnal Ethnographies. Following Cortázar in the Milongas of Buenos Aires. - Marta Savigliano, Angora Matta. Fatal Acts on NorthSouth Translation, 141-66. Middletown: Wesleyan University Press.

\section{Solnit, Rebecca}

2004 Hope in the Dark. Untold Histories, Wild Possibilities. New York: Nation Books.

\section{Trouillot, Michele-Rolph}

2003 Anthropology and the Savage Slot. The Poetics and Politics of Other- 
ness. - Michele-Rolph Trouillot, Global Transformations. Anthropology and the Modern World, 7-28. New York: Palgrave. 